\title{
Table of international cases, treaties and other international instruments
}

\section{TABLE OF INTERNATIONAL CASES}

Reparation for Injuries Suffered in the Service of the United Nations, Advisory Opinion, Declaration of Judge Winiarski, 11 April 1949

Case Concerning Pulp Mills on the River Uruguay (Argentina v Uruguay), Judgment, 20 April 2010 ................................................ 119, 200-201, 225

Indus Waters Kishenganga Arbitration (Pakistan v India), Partial Award, 18 February 2013

Arbitral Tribunal Constituted under Annex VII to the United Nations Convention on the Law of the Sea (Philippines v China), Award, 12 July 2016

\section{TABLE OF INTERNATIONAL TREATIES AND OTHER INTERNATIONAL INSTRUMENTS}

1920 Svalbard Treaty (Paris, 9 February 1920) in force 14 August 1925 237

1960 Indus Waters Treaty between the Government of India and the Government of Pakistan (Karachi, 19 September 1960), 419 UNTS 126, in force 1 January 1961 178, 179, 187, 188-92, 219, 225, 229, 233

1971 Convention on Wetlands of International Importance, especially as Waterfowl Habitat (Ramsar, 2 February 1971) 11 ILM 963, in force

21 December 1975 90-91, 236

Convention on the Protection of the Alps (Salzburg, 7 November 1971)

OJ L61, 12/03/1996, p. 32, in force 6 March 1995 237

1972 Convention Concerning the Protection of the World Cultural and Natural Heritage (Paris, 16 November 1972) 1037 UNTS 151, in force 17 December 1975 42, 236, 239 Convention on the Prevention of Marine Pollution by Dumping of Wastes and Other Matter (London, 29 December 1972) 1046 UNTS 120, in force 30 August 1975

1973 Convention on International Trade in Endangered Species of Wild Fauna and Flora (CITES) (Washington DC, 3 March 1973) 993 UNTS 243, in force 1 July 1975 91, 226, 236 
International Convention for the Prevention of Pollution from Ships (London, 11 February 1973), 12 ILM 1319 (1973), in force 19 February 1983, as modified by the Protocol of 1978 (London, 17 February 1978) 1340 UNTS 61, in force 2 October 1983 $48,52,96$

1978 Regional Convention for Cooperation on the Protection of the Marine Environment from Pollution (Arabian Gulf/Gulf of Oman Convention), (Kuwait, 24 April 1978), in force 1 July 1979 .... 30-52, 54-61 passim, 66, 69, $71,73,95-6,186$

Protocol Concerning Regional Cooperation in Combating Pollution by Oil and Other Harmful Substances in Cases of Emergency (Regional Cooperation Protocol), (Kuwait, 24 April 1978), unreported, in force 20 August 1985 37, 45-6, 47, 54, 58, 60, 86, 95

1979 Convention on the Conservation of Migratory Species of Wild Animals (Bonn, 23 June 1979) 19 ILM 15, in force 1 November 1983 91,236 Convention on Long-Range Transboundary Air Pollution (Geneva, 13 November 1979) 1302 UNTS 217, in force 16 March 1983 160,215

1981 Colombo Declaration on the South Asia Co-operative Environment Programme, 25 February 1981 186

1982 United Nations Convention on the Law of the Sea (Montego Bay, 10 December 1982), 1833 UNTS 3, in force 16 November 1994 35,85 ,

Regional Convention for the Conservation of the Red Sea and Gulf of Aden (Jeddah, 1982), ECOLEX B7 p. 982:13, in force 20 August 1985 ...... 37, 49, 53-68, 71, 73, 95, 121, 196

Protocol Concerning Regional Cooperation in Combating Pollution by Oil and Other Harmful Substances in Cases of Emergency (Jeddah, 14 February 1982) unreported, in force 20 August 1985 54

Final Act of the Jeddah Plenipotentiary Regional Conference on the Conservation of the Marine Environment and Coastal Areas in the Red Sea and Gulf of Aden (Jeddah, 13-15 February 1982)

Action Plan for the Conservation of the Marine Environment and Coastal Areas in the Red Sea and Gulf of Aden (Jeddah, 14 February 1982) in force 20 August 1985 54-5

1985 Agreement on the Conservation of Nature and Natural Resources (Conservation Agreement), opened for signature 9 July 1985, 15 EPL 64 (1985), not in force $74,124,148-55,160,173,175,235$ Charter of the South Asian Association for Regional Cooperation (Dhaka, December 18 1985) 184

1989 Convention on the Control of Transboundary Movements of Hazardous Wastes and their Disposal (Basel, 22 March 1989) 1673 UNTS 126, in force 5 May 1992

Protocol Concerning Marine Pollution Resulting from Exploration and Exploitation of the Continental Shelf (Kuwait, 29 March 1989), unreported, in force 17 February 1990 $37,45,47-50,52$

1990 International Convention on Oil Pollution Preparedness, Response and Cooperation (London, 30 November 1990) 1891 UNTS 51, in force 13 May 1995 96 
Protocol for the Protection of the Marine Environment against Pollution from Land-Based Sources (Kuwait, 21 February 1990) ...... 37, 34, 50, 51, 61

1991 Convention on Environmental Impact Assessment in a Transboundary Context (Espoo, 25 February 1991), 30 ILM (1991) 802, in force 27 June 1997 $86,144,146,201,219,225,229,230$ Protocol on Environmental Protection to the Antarctic Treaty (Madrid, 4 October 1991) 30 ILM 1455 (1991), in force 14 January 1998 237

1992 United Nations Declaration on Environment and Development, Rio de Janeiro, 1992. UN Doc A/CONF.151/5/Rev.1 (1992) 208 Convention on the Protection and Use of Transboundary Watercourses and Lakes (Helsinki, 17 March 1992), 31 ILM (1992) 1312, in force 6 October 1996 $98,191,219$

United Nations Framework Convention on Climate Change (Rio de Janeiro,

9 May 1992), 1771 UNTS 107, in force 21 March 1994 236

Convention on Biological Diversity (Rio de Janeiro, 22 May 1992), 31 ILM 822, in force 29 December 1993 ....... 36-9, 62, 64, 66, 86, 91, 113, 154, 178, $218,226,236,239$

Convention on the Protection of the Marine Environment of the Baltic Sea Area (Helsinki, 9 April 1992) 1507 UNTS 167, in force 17 January 2000

Agreement on Cooperation in the Field of Joint Management and

Conservation of Interstate Water Resources (Almaty, 18 February 1992) accessed 20 November 2014 at http://www.caee.utexas.edu/prof/mckinney/ papers/aral/agreements/ICWC-Feb18-1992.pdf $74,101-2$

1993 International Convention for the Prevention of Pollution from Ships (London, 2 February 1973) 12 ILM 1319, in force 12 October 1983 .... 48, 96 Agreement on Joint Actions for Addressing the Problems of the Aral Sea and its Coastal Area, Improving the Environment, and Ensuring the Social and Economic Development of the Aral Sea Region (Kzyl-Orda, 26 March 1993)

1994 Convention to Combat Desertification in Those Countries Experiencing Serious Drought and/or Desertification, Particularly in Africa (Paris, 14 October 1994) 1954 UNTS 3, in force 26 December 1996

Protocol for the Protection of the Mediterranean Sea Against Pollution Resulting from Exploration and Exploitation of the Continental Shelf and the Seabed and its Subsoil (Madrid, 14 October 1994)

1995 Convention for the Protection of the Marine Environment and the Coastal Region of the Mediterranean (Barcelona, 10 June 1995) 1102 UNTS 27, in force 9 July 2004

Agreement on the Cooperation for the Sustainable Development of the Mekong River Basin (Chiang Rai, 5 April 1995), 2069 UNTS 3, in force 5 April 1995 $124,129-48,173-4,229$ Agreement on the Establishment of the Tumen River Area Development Coordination Committee (New York, 6 December 1995), unreported, in force 6 December 1995 177,205 
Agreement on the Establishment of the Consultative Commission for the Development of the Tumen River Economic Development Area and Northeast Asia (New York, 6 December 1995), unreported, in force 6 December 1995

Cairo Declaration Concerning the Formation of the Regional Organization for the Conservation of the Environment of the Red Sea and Gulf of Aden, PERSGA, Council Decision No. (CD-1-GM1-26/9/1995)

Memorandum of Understanding on Environmental Principles Governing the Tumen River Economic Development Area and North East Asia, New York, 1995

1996 Agreement on Cooperation over Water Management Issues (Chardjev, 16 January 1996)

Agreement on the Use of Fuel and Water Resources, Construction and Operation of Gas Pipelines in Central Asian Region (Tashkent, 5 April 1996)

Mahakali Agreement

1997 Convention on the Law of Non-Navigable Uses of International

Watercourses (New York, 21 May 1997, by UNGA Res. 51/229), 36 ILM

(1997) 700, in force August 2014 $85,104,190-91$

1998 Convention on Access to Information, Public Participation in

Decision-Making and Access to Justice in Environmental Matters (Aarhus, 25 June 1998) 2161 UNTS 447, in force 30 October 2001 93, 94, 99 Agreement on the Use of Water and Energy Resources of the Syrdarya Basin (Bishkek, 17 March 1998) 103 Agreement on Cooperation in the Area of Environment and Rational Nature Use (Bishkek, 17 March 1998)

Agreement on the Main Principles of Interactions in the Field of Rational Use and Protection of the Transboundary Watercourses of the CIS (Moscow, 11 September 1998) 103

Malé Declaration on Control and Prevention of Air Pollution and its Likely Transboundary Effects for South Asia, 1998 See: http://www.rrcap.ait.asia/ male/Pages/Agreement.aspx $160,179,187,188,194-5,212$ Protocol on the Control of Marine Transboundary Movements and Disposal of Hazardous Wastes and other Wastes (Tehran, 17 March 1998), Ecolex, B7 p. 978:31/D, in force 21 August 2005 37,52

1999 Agreement about the Status of the International Fund for Saving the Aral Sea (Ashgabat, 9 April 1999). $74,102,103,104-5,106,122$ Agreement on the Parallel Operation of the Energy Systems of Central Asian States (Bishkek, 17 June 1999) 103

2002 Agreement on Transboundary Haze Pollution (Kuala Lumpur, 10 June 2002), unreported, in force 25 November 2003 $125,127,149,151$, $157-68,175,212$

2003 Framework Convention for the Protection of the Marine Environment of the Caspian Sea (Tehran, 4 November 2003), 44 ILM 1 (2005), in force 12 August 2006 71, 73, 82-100, 111, 114, 120, 121, 196 Framework Convention on the Protection and Sustainable Development of the Carpathians (Kyiv, 22 May 2003) in force January 2006 
Protocol on Strategic Environmental Assessment to the Convention on Environmental Impact Assessment in a Transboundary Context (Kiev, 21 May 2003) unreported, in force 11 July 2010

2004 Memorandum of Understanding on Cooperation in the Field of the Environment between the South Asian Association for Regional Cooperation and the South Asia Co-operative Environment Programme, unreported July 2004

2005 Agreement on the Establishment of the ASEAN Centre for Biodiversity (Capitals of each member state, 2005), in force 8 July 2009

Protocol Concerning the Conservation of Biological Diversity and the Establishment of Network of Protected Areas in the Red Sea and Gulf of Aden (Jeddah, 12 December 2005) Ecolex B7 p. 982:13/B, not in force ... 55,

Protocol Concerning the Protection of the Marine Environment from Land-Based Activities in the Red Sea and Gulf of Aden (Jeddah, 25 September, 2005) unreported, not in force

2006 Framework Convention on Environmental Protection for Sustainable Development in Central Asia (Ashgabat, 22 November 2006) TRE-143806, not in force. Accessed 20 November 2014 at http://www.ecolex.org/ server2.php/libcat/docs/TRE/Full/En/TRE-143806.pdf ... 73-123, 173, 175,

Host Country Agreement between the Government of the Republic of the Philippines and the ASEAN Centre for Biodiversity (Manila, 8 August, 2006)

2007 Charter of the Association of Southeast Asian Nations (Singapore, 20

November, 2007)

2008 Statute of the Interstate Commission for Water Coordination of Central Asia (Almaty, 18 September 2008) 74, 101-2, 103, 104-7, 122 United Nations Declaration on the Rights of Indigenous Peoples, Resolution adopted by the General Assembly, 61/292, 13 September 2007 (United Nations 2008) 236

2009 Protocol Concerning the Exchange of Personnel and Equipment in Case of Marine Emergency (Jeddah, 1 July 2009) unreported, not in force ...... 55, 58,

2010 Convention on Cooperation on Environment (Thimphu, 28-29 April 2010), unreported, in force 23 October 2013 $179,185,187,192$

2011 Protocol Concerning Regional Preparedness, Response and Cooperation in Combating Oil Pollution Incidents (Aktau, 12 August 2011) unreported, not in force $37,45-7,54,58,60,86,95-7$ Agreement on Rapid Response to Natural Disasters (Maldives, 10-11 November 2011), unreported, not in force at November 2014 179,185 , $192-3$

2012 Protocol on Environmental Impact Assessment in a Transboundary Context to the Framework Convention for the Protection of the Marine Environment of the Caspian Sea, 2012 $86,93-5,111-13$ 
Protocol for the Protection of the Caspian Sea against Pollution from Land-Based Sources and Activities (Moscow, 12 December 2012) unreported, not in force $86,95-8,114-15$ Bangkok Resolution on ASEAN Environmental Cooperation (Bangkok, 26 September 2012) Vladivostok Declaration, 10 October 2012 ............................................ 204

2013 Ulaanbaatar Declaration, 30 October 2013 ........................................ 211

2014 Protocol for the Conservation of Biological Diversity (Ashgabat, 30 May 2014) unreported, not in force $86,90-93$ Framework Agreement for Energy Cooperation (Electricity) (Kathmandu, 27 November 2014), unreported, not in force $179,187,193$ Kathmandu Declaration, Eighteenth SAARC Summit, Kathmandu, Nepal, 26-27 November 2014 185,186 Yanbian Declaration, 17 September 2014 ......................................... 212

2016 Seoul Declaration, 28 April 2016 204 
Simon Marsden - 9781784718091

Downloaded from PubFactory at 04/26/2023 01:50: 08 PM via free access 